\title{
THE LAST DECADE OF MARKETING RESEARCH: THE CASE OF EUROPEAN JOURNAL OF MARKETING
}

Adnan DUYGUN ${ }^{1}$

S. Ahmet MENTEŞ ${ }^{2}$
Received (Başvuru Tarihi): 15/12/2018

Accepted (Kabul Tarihi): 13/03/2019

Published Date (Yayın Tarihi): 12/05/2019

\section{ABSTRACT}

JEL Codes: M30, M31, M39
This study aims to present a bibliometric analysis of the research papers published in the European Journal of Marketing (EJM) from the year 2008 to 2017. According to results, 762 research papers were published in the European Journal of Marketing from the year 2008 to 2017. The distribution of top three subjects is as follows; product and branding (148 papers, $19.42 \%)$, marketing communications (119 papers, $15.62 \%$ ) and consumer behaviour (109 papers, 14.30\%). The top three article contributing countries are the UK, Australia, and the USA. The results also exhibit that most of the research papers (543 papers, $71.26 \%)$ have 51 or more references. Finally, approximately half of the research papers (352 papers, $46.20 \%$ ) are cited up to ten times. The results are important for the guidance of academicians and researchers who study in marketing.

Keywords: Marketing Research, Bibliometric Analysis, European Journal of Marketing

\section{PAZARLAMA ARAŞTIRMALARININ SON ON YILI: EUROPEAN JOURNAL OF MARKETING ÖRNEĞI}

$\ddot{O} Z$

JEL Kodlarl: M30, M31, M39
Bu araștırma, 2008-2017 yılları arasında European Journal of Marketing dergisinde yayınlanan araştırma makalelerinin bibliyometrik analizinin ortaya konmasını amaçlamaktadır. Araştırmada elde edilen sonuçlara göre European Journal of Marketing dergisinde 2008-2017 yılları arasında 762 araştırma makalesi yayınlanmıştır. Konu dağllımlarına bakıldığında ilk üç konu; ürün ve markalama (148 makale, \%19.42), pazarlama iletişimi (119 makale, \%15.62) ve tüketici davranışl (109 makale, \%14.30) şeklindedir. En çok araştırma makalesi katkısı yapan ilk üç ülke ise UK, Australia ve USA'dir. Benzer şekilde, makalelerde kullanılan referans sayılarının büyük çoğunluğunun (543 makale, \%71.26) 51 ve üzeri olduğu tespit edilmiştir. Son olarak, araştırma makalelerinin yaklaşık yarısı (352 makele, \%46.20) on kereye kadar atıf almıștır. Elde edilen sonuçlar pazarlama alanında çalışan akademisyen ve araştırmacılara yol göstermesi açısından önem taşımaktadır.

Anahtar Kelimeler: Pazarlama Araştırması, Bibliyometrik Analiz, European Journal of Marketing

${ }^{1}$ Asst. Prof., Ph.D., Istanbul Gelisim University, aduygun@gelisim.edu.tr ${ }^{2}$ Assoc. Prof., Ph.D., Tekirdag Namik Kemal University, amentes@ @ku.edu.tr https://orcid.org/0000-0003-4026-4054 https://orcid.org/0000-0001-7787-6287 


\section{INTRODUCTION}

The term bibliometrics was first used by Pritchard (1969) as "the application of mathematical and statistical methods to books and other means of communication”. Similarly, Broadus (1987) defines bibliometrics as "the quantitative study of physical published units, or of bibliographic units, or of the surrogates for either". Bibliometrics use quantitative analysis of empirical data in published literature to explore the trends of publication within an area of study (De Bellis, 2009), this enables researchers to examine the body of literature in their field in order to identify major themes (Grant, Cottrell, Cluzeau and Fawcett, 2000; Vogel and Güttel, 2013). Bibliometrics can also be used to establish statistical models of scholarly communication flow (Borgman, 1999). In the literature, bibliometric studies were made in many areas (Podsakoff, MacKenzie, Podsakoff and Bachrach, 2008; Bonilla, Merigó and Torres-Abad, 2015; Coupé, 2003; Baltagi, 2007; Fagerberg, Fosaas and Sapprasert, 2012; Landstrom, Harirchi and Astrom, 2012).

Bibliometrics is mainly a form of statistical analysis of publications, which provides quantitative insight into academic literature (Benckendorff and Zehrer, 2013). Basically, the bibliometric analysis provides insight about how the growth of literature and the flow of knowledge within a specified field evolves over a period of time by analyzing information gathered in the database, such as keywords, citations, authors, and type of journals consulted (VanRaan, 2005). Based on which information it uses in an analysis, bibliometrics includes different methods (Leung, Sun and Bai, 2017).

Bibliometric analysis has become an increasingly significant issue in business discipline including marketing (Dabirian, Diba, Tareh and Treen, 2016; Samiee and Chabowski, 2012; Polonsky and Ringer, 2012), sales management (Johnson, 2006), strategic management (Vogel and Güttel, 2013), accounting (Zhong, Geng, Liu, Gao and Chen, 2016), supply chain management (Asgari, Nikbakhsh, Hill and Farahani, 2016), advertising (Kim and McMillan, 2008), and others.

Bibliometric analysis is a vital tool to comprehend the developments in discipline because it allows researchers to identify the evolution of a field as well as the contributions made to the field or associated fields (Baumgartner and Pieters 2003; Hubbard, Norman and Miller, 2005). Similarly, bibliometric analysis of journals provides journals an opportunity to reflect on what they have achieved at various stages (Schlegelmilch 2003; Zinkhan and Leigh 1999). 
The EJM is a leading marketing journal launched in 1967. The journal is indexed in the Journal Citation Reports of the Web of Science. In 1976, it became a bimonthly journal; in 1977, it began to publish eight issues per year. In 1986, the EJM grew to ten issues per year, and in 1989, it became a monthly journal (Martínez-López, Merigó, Valenzuela-Fernández and Nicolás, 2018). The EJM presents itself as receptive to new and controversial topics, and new, as well as developments that challenge existing theories and paradigms. The journal also serves as a catalyst for solving marketing problems and dilemmas, and as such, it is already regarded as an essential resource by many leading industry figures and supplying libraries (European Journal of Marketing web site, 2018).

Organizing a special activity such as a review (Van Fleet et al., 2006), a special issue (Meyer and Winer, 2014), an editorial (Barley, 2016; Shugan, 2006) or a bibliometric overview (Schwert, 1993), of a journal is very common when this journal celebrates an anniversary. The EJM turned 50 years old in 2017. Inspired by this anniversary, the objective of this study aims to present a bibliometric overview of the leading trends of the journal during the last decade.

\section{MAIN OBJECTIVE AND METHODOLOGY}

This study aims to present an evaluation of the research papers published in the European Journal of Marketing (EJM) from the year 2008 to 2017 by using bibliometric analysis. The data required for the study is gathered from the research papers published in the European Journal of Marketing website from the year 2008 to 2017. Only research papers are included in the study.

The main objective of this study is to answer the following questions:

- How is the yearly distribution of research papers published in the EJM?

- What is the subject distribution of research papers?

- How is the distribution of research papers according to the number of authors and authors' geographical region?

- How is the distribution of research papers according to the authors' country of residence?

- How is the distribution of research papers according to their number of references?

- How is the distribution of research papers according to their number of citations? 


\section{RESULTS AND DISCUSSION}

Yearly distribution of research papers published in the EJM is displayed in Table 1. The number of published research papers increased from 49 in 2008 to 88 in 2017. In 2014 the number of research papers published in the EJM reached a record high of 100 papers. The second highest number of research papers was published in 2016 (91 papers).

Table 1. Yearly Distribution of Research Papers Published in The EJM

\begin{tabular}{ccc}
\hline Year & Number of Research Papers & $\%$ \\
\hline 2008 & 49 & $\mathbf{6 . 4 3}$ \\
2009 & 51 & $\mathbf{6 . 6 9}$ \\
2010 & 77 & $\mathbf{1 0 . 1 1}$ \\
2011 & 69 & $\mathbf{9 . 0 6}$ \\
2012 & 73 & $\mathbf{9 . 5 8}$ \\
2013 & 85 & $\mathbf{1 1 . 1 5}$ \\
2014 & 100 & $\mathbf{1 3 . 1 2}$ \\
2015 & 79 & $\mathbf{1 0 . 3 7}$ \\
2016 & 91 & $\mathbf{1 1 . 9 4}$ \\
2017 & 88 & $\mathbf{1 1 . 5 5}$ \\
TOTAL & $\mathbf{7 6 2}$ & $\mathbf{1 0 0 . 0 0}$ \\
\hline
\end{tabular}

Table 2. Subject Distribution of Research Papers

\begin{tabular}{|c|c|c|c|c|c|c|c|c|c|c|c|c|}
\hline \multirow{2}{*}{ Subject } & \multicolumn{10}{|c|}{ Year } & \multirow[t]{2}{*}{ Total } & \multirow[t]{2}{*}{$\%$} \\
\hline & 2008 & 2009 & 2010 & 2011 & 2012 & 2013 & 2014 & 2015 & 2016 & 2017 & & \\
\hline Marketing management and strategies & 9 & 11 & 6 & 15 & 15 & 10 & 6 & 9 & 18 & 7 & 106 & 13.91 \\
\hline Product and branding & 10 & 4 & 17 & 8 & 24 & 8 & 15 & 18 & 24 & 20 & 148 & 19.42 \\
\hline Price and pricing strategies & - & 2 & 2 & - & 3 & 2 & 3 & 2 & 2 & 2 & 18 & 2.36 \\
\hline Distribution channels and logistics & 2 & 10 & 9 & 10 & 3 & 8 & 16 & 5 & 2 & 1 & 66 & 8.66 \\
\hline Marketing communications & 5 & 3 & 18 & 4 & 11 & 10 & 16 & 11 & 19 & 22 & 119 & 15.62 \\
\hline Sales and customer relations & 6 & 8 & 3 & 7 & 6 & 16 & 11 & 8 & 8 & 7 & 80 & 10.50 \\
\hline Consumer behavior & 9 & 1 & 13 & 13 & 3 & 15 & 15 & 13 & 9 & 18 & 109 & 14.30 \\
\hline International marketing & 2 & 4 & 5 & 3 & 1 & - & 4 & 1 & 1 & 2 & 23 & 3.02 \\
\hline Services marketing & 4 & 5 & 2 & 3 & 4 & 9 & 9 & 8 & 2 & 6 & 52 & 6.83 \\
\hline Others & 2 & 3 & 2 & 6 & 3 & 7 & 5 & 4 & 6 & 3 & 41 & 5.38 \\
\hline TOTAL & 49 & 51 & 77 & 69 & 73 & 85 & 100 & 79 & 91 & 88 & 762 & 100.00 \\
\hline
\end{tabular}

According to Table 2, the results exhibit that, for the studied period, "product and branding" is the most popular research paper subject with $19.42 \%$ (148 papers). The subject distribution for the rest of the papers is as follows:

- "Marketing communications" 15,62\% (119 papers)

- “Consumer behavior" 14.30\% (109 papers)

- "Marketing management and strategies" $13.91 \%$ (106 papers)

- "Sales and customer relations" $10.50 \%$ (80 papers)

- "Distribution channels and logistics" 8.66\% (66 papers)

- "Services marketing" $6.83 \%$ (52 papers)

- "International marketing" 3.02\% (23 papers)

- "Price and pricing strategies" $2.36 \%$ (18 papers) 
- The "others" 5.38\% (41 papers).

Table 3. Distribution of Research Papers According to The Authors' Geographical Region

\begin{tabular}{|c|c|c|c|c|c|c|c|c|c|c|c|c|}
\hline \multirow{2}{*}{$\begin{array}{l}\text { Geographical } \\
\text { Region }\end{array}$} & \multicolumn{10}{|c|}{ Year } & \multirow{2}{*}{ Total } & \multirow{2}{*}{$\%$} \\
\hline & 2008 & 2009 & 2010 & 2011 & 2012 & 2013 & 2014 & 2015 & 2016 & 2017 & & \\
\hline Europe & 67 & 90 & 104 & 83 & 109 & 131 & 106 & 107 & 89 & 111 & 997 & 51.29 \\
\hline North America & 11 & 16 & 32 & 31 & 20 & 29 & 74 & 31 & 73 & 38 & 355 & 18.26 \\
\hline South America & - & - & 1 & - & 2 & - & 6 & 1 & 3 & 3 & 16 & 0.82 \\
\hline Asia & 12 & 4 & 12 & 25 & 23 & 29 & 33 & 22 & 24 & 35 & 219 & 11.27 \\
\hline Africa & - & - & 1 & - & - & - & - & - & - & 2 & 3 & 0.15 \\
\hline Australia & 15 & 12 & 31 & 27 & 37 & 33 & 48 & 45 & 57 & 49 & 354 & 18.21 \\
\hline TOTAL & 105 & 122 & 181 & 166 & 191 & 222 & 267 & 206 & 246 & 238 & 1944 & 100.00 \\
\hline
\end{tabular}

Table 3 displays the distribution of research papers according to the authors' geographical region. Most of the contributing authors to the European Journal of Marketing are from Europe 51.29\%, (997 authors). This is followed by North America 18.26\% (355 authors) and Australia $18.21 \%$ (354 authors). This is followed by the contributions made by Asia $11.21 \%$ (219 authors), South America 0.82\% (16 authors) and Africa 0.15\% (3 authors).

Table 4. Top Three Research Paper Contributing Countries According to The Distribution of Authors' Country of Residence

\begin{tabular}{cccccccccccc}
\hline & \multicolumn{10}{c}{ Year } & Total \\
\cline { 2 - 13 } & $\mathbf{2 0 0 8}$ & $\mathbf{2 0 0 9}$ & $\mathbf{2 0 1 0}$ & $\mathbf{2 0 1 1}$ & $\mathbf{2 0 1 2}$ & $\mathbf{2 0 1 3}$ & $\mathbf{2 0 1 4}$ & $\mathbf{2 0 1 5}$ & $\mathbf{2 0 1 6}$ & $\mathbf{2 0 1 7}$ & \\
\hline UK & 37 & 23 & 50 & 42 & 49 & 58 & 33 & 43 & 43 & 47 & $\mathbf{4 2 5}$ \\
Australia & 15 & 11 & 27 & 18 & 33 & 32 & 44 & 36 & 48 & 46 & $\mathbf{3 1 0}$ \\
USA & 7 & 13 & 27 & 30 & 17 & 25 & 61 & 23 & 64 & 33 & $\mathbf{3 0 0}$ \\
\hline
\end{tabular}

As displayed in Table 4, the top three research paper contributing countries according to the distribution of authors' country of residence are UK, Australia, and USA. UK is the top contributor country with a total of 425 authors. UK is followed by Australia (310 authors) and USA (300 authors).

Table 5. Distribution of Research Papers According to Their Number of References

\begin{tabular}{|c|c|c|c|c|c|c|c|c|c|c|c|c|}
\hline \multirow{2}{*}{$\begin{array}{c}\text { Reference } \\
\text { Number }\end{array}$} & \multicolumn{10}{|c|}{ Year } & \multirow{2}{*}{ Total } & \multirow{2}{*}{$\%$} \\
\hline & 2008 & 2009 & 2010 & 2011 & 2012 & 2013 & 2014 & 2015 & 2016 & 2017 & & \\
\hline $1-10$ & - & - & - & - & - & - & - & - & 3 & - & 3 & 0.39 \\
\hline $11-20$ & 1 & 2 & 3 & 3 & - & 1 & - & - & 3 & - & 13 & 1.71 \\
\hline $21-30$ & 3 & 2 & 5 & 3 & 3 & 4 & 2 & 2 & 3 & 1 & 28 & 3.67 \\
\hline $31-40$ & 8 & 6 & 9 & 6 & 5 & 4 & 6 & 4 & 1 & 7 & 56 & 7.35 \\
\hline $41-50$ & 4 & 7 & 3 & 10 & 14 & 10 & 26 & 10 & 17 & 18 & 119 & 15.62 \\
\hline 51 or higher & 33 & 34 & 57 & 47 & 51 & 66 & 66 & 63 & 64 & 62 & 543 & 71.26 \\
\hline TOTAL & 49 & 51 & 77 & 69 & 73 & 85 & 100 & 79 & 91 & 88 & 762 & 100.00 \\
\hline
\end{tabular}

Table 5 exhibits the distribution of research papers according to their number of references. The ratio of research papers with 51 or higher number of references is $71.26 \%$ (543 papers), papers with 41 to 50 references are $15.62 \%$ (119 papers), papers with 31 to 40 references are $7.35 \%$ (56 papers), papers with 21 to 30 references are $3.67 \%$ (28 papers) and 
papers with 11 to 20 references are $1.71 \%$ (13 papers) and finally papers with 1 to 10 references are $0.39 \%$ (3 papers).

Table 6. Distribution of Research Papers According to Their Number of Citations

\begin{tabular}{|c|c|c|c|c|c|c|c|c|c|c|c|c|}
\hline \multirow{2}{*}{$\begin{array}{l}\text { Citation } \\
\text { Number }\end{array}$} & \multicolumn{10}{|c|}{ Year } & \multirow{2}{*}{ Total } & \multirow{2}{*}{$\%$} \\
\hline & 2008 & 2009 & 2010 & 2011 & 2012 & 2013 & 2014 & 2015 & 2016 & 2017 & & \\
\hline 0 & 0 & 0 & 1 & 0 & 1 & 3 & 6 & 5 & 45 & 71 & 132 & 17.32 \\
\hline $1-10$ & 7 & 9 & 25 & 28 & 34 & 41 & 75 & 70 & 46 & 17 & 352 & 46.20 \\
\hline $11-20$ & 13 & 19 & 22 & 18 & 18 & 32 & 16 & 4 & - & - & 142 & 18.64 \\
\hline $21-30$ & 9 & 7 & 11 & 12 & 13 & 3 & 2 & - & - & - & 57 & 7.48 \\
\hline $31-40$ & 5 & 7 & 5 & 2 & 3 & 4 & 1 & - & - & - & 27 & 3.54 \\
\hline $41-50$ & 5 & 6 & 6 & 6 & 2 & 2 & - & - & - & - & 27 & 3.54 \\
\hline 51 or higher & 10 & 3 & 7 & 3 & 2 & - & - & - & - & - & 25 & 3.28 \\
\hline TOTAL & 49 & 51 & 77 & 69 & 73 & 85 & 100 & 79 & 91 & 88 & 762 & 100.00 \\
\hline
\end{tabular}

Data gathered from the website of the European Journal of Marketing is used to construct Table 6. The table displays the distribution of research papers according to the number of citations they get as of 01.01.2018. Almost half of the research papers published in EJM (46.20\%) are cited up to ten times by other researchers. The research papers that never get cited is $17.32 \%$.

\section{SUMMARY AND CONCLUSIONS}

This study exhibits the bibliometric analysis of research papers published at EJM for the period of 2008-2017. The results can be summarized as follows:

- A total of 762 research articles was published in the EJM between 2008 and 2017.

- The top three popular research paper subjects are: "product and branding" (19.42\% of all research papers), "marketing communications" (15.62\% of all research papers) and "consumer behavior" (14.30\% of all research papers).

- The total number of research paper authors is 1944. More than half $(51.29 \%, 997$ authors) of these authors are located in Europe. Following Europe, regions with the highest number of contributions are North America (355 papers, 18.26\%) and Australia (354 papers, $18.21 \%)$.

- The UK is the country, with the highest number of authors (425 authors) that contributed to the European Journal of Marketing. This is followed by Australia (310 authors) and the USA (300 authors).

- The number of research papers with 51 or more references is $543(71.26 \%)$.

- About half of the research papers with 352 (46.20\%) are cited up to ten times.

For the period that the study covers EJM always ranks among the top fifty marketing journals (Scimago Institutions Rankings web site, 2019). This is an explicit proof that EJM is 
one of the most marketing prestigious journals, which is indexed at the SSCI (Social Sciences Citation Index).

The results are expected to help marketing scholars about the evaluation of marketing research topics throughout the years. This may assist marketing researchers to focus their areas of interest and studies parallel to the changing trends in the area of marketing. There is no doubt that following the trends in marketing research will provide marketing researchers the opportunity to get their studies published more easily and get more citations.

Similar studies for other fields of Business discipline such as management, finance, and computer information systems ect also should be encouraged. So, scholars and researchers can follow the changing trends and keep themselves up to date in their field of research.

The results clearly exhibit that the published research papers have an authorship concentration dominated by UK, Australia, and US. This finding requires further research to understand if such an authorship concentration exists in similar journals. The findings may not only help to understand the editorial policies of similar journals but also hint us which countries dominate the marketing research. 


\section{REFERENCES}

Asgari, N., Nikbakhsh, E., Hill, A. and Farahani, R. Z. (2016). "Supply Chain Management 1982-2015: A Review", IMA Journal of Management Mathematics, Volume 27, Issue 3, 353-379.

Baltagi, B. H. (2007). "Worldwide Econometrics Rankings: 1989-2005”, Econometric Theory, Vol. 23 No. 05 , 952-1012.

Barley, S. R. (2016). “60th Anniversary Essay: Ruminations on How We Became a Mystery House and How We Might Get Out”, Administrative Science Quarterly, Vol. 61(1), 1-8.

Baumgartner, H. and Pieters, R. (2003).“The Structural Influence of Marketing Journals: A Citation Analysis of The Discipline and Its Subareas Over Time”, Journal of Marketing, Vol. 67 No. 2, 123-139.

Benckendorff, P. and Zehrer, A. (2013). “A Network Analysis of Tourism Research”, Annals of Tourism Research, Vol. xx No. xx, 121-149.

Bonilla, C. A., Merigó, J. M. and Torres-Abad, C. (2015). "Economics in Latin America: A Bibliometric Analysis", Scientometrics, Volume 105, Issue 2, 1239-1252.

Borgman, C. L. (1999). "Books, Bytes, and Behavior: Rethinking Scholarly Communication for a Global Information Infrastructure”, Information Services \& Use, Volume 19 Issue 2, 117-121.

Broadus, R. N. (1987). "Toward a Definition of "bibliometrics"”, Scientometrics, Vol. 12 No. 5-6, 373-379.

Coupé, T. (2003). "Revealed Performances: Worldwide Rankings of Economists and Economics Departments, 1990-2000", Journal of the European Economic Association, Vol. 1 No. 6, 1309-1345.

Dabirian, A., Diba, H., Tareh, F. and Treen, E. (2016). “A 23-Year Bibliometric Study of The Journal of Food Products Marketing”, Journal of Food Products Marketing, Vol. 22 No. 5, 610-622.

De Bellis, N. (2009). Bibliometrics and Citation Analysis: From the Science Citation Index to Cybermetrics. Lanham, Maryland: Scarecrow Press Inc.

European Journal of Marketing. Retrieved from http://www.emeraldgrouppublishing.com/ejm.htm (03 January 2018).

Fagerberg, J., Fosaas, M. and Sapprasert, K. (2012). "Innovation: Exploring The Knowledge Base”, Research Policy, Volume 41 Issue 7, 1132-1153.

Grant, J., Cottrell, R., Cluzeau, F. and Fawcett, G. (2000). "Evaluating "payback” on Biomedical Research from Papers Cited in Clinical Guidelines: Applied Bibliometric Study”, BMJ, Volume 320, 1107-1111. 
Hubbard, R., Norman, A. T. and Miller, C. E. (2005). A citation analysis of articles dealing with marketing history, thought, and theory. In The future of marketing's past. Edited by Leighann C. Neilson, 175-81. Long Beach, CA: Association for Historical Research in Marketing.

Johnson, M. S. (2006). “A Bibliometric Review of The Contribution of Attribution Theory to Sales Management”, Journal of Personal Selling \& Sales Management, Vol. XXVI No. 2, 181-195.

Kim. J. and McMillan, S. J. (2008). "Evaluation of Internet Advertising Research: A Bibliometric Analysis of Citations from Key Sources”, Journal of Advertising, 37(1), 99-112.

Landstrom, H., Harirchi, G. and Astrom, F. (2012). "Entrepreneurship: Exploring The Knowledge Base”, Research Policy, Volume 41 Issue 7, 1154-1181.

Leung, X., Sun, J. and Bai, B. (2017). "Bibliometrics of Social Media Research: A Co-Citation and Co-Word Analysis”, International Journal of Hospitality Management, Volume 66, 35-45.

Martínez-López, F. J., Merigó, J. M., Valenzuela-Fernández, L. and Nicolás, C. (2018). "Fifty Years of The European Journal of Marketing: A Bibliometric Analysis”, European Journal of Marketing, Vol. 52 No. 1/2, 439468.

Meyer, R. and Winer, R. S. (2014). "Introduction to The JMR 50th Anniversary Special Section", Journal of Marketing Research, Vol. 51 No. 1, 83-83.

Podsakoff, P. M., MacKenzie, S. B., Podsakoff, N. P. and Bachrach, D. G. (2008). "Scholarly Influence in The Field of Management: A Bibliometric Analysis of The Determinants of University and Author Impact in The Management Literature in The Past Quarter Century”, Journal of Management, Volume 34 Issue 4, 641-720.

Polonsky, M. J. and Ringer, A. (2012). “Twenty Years of The Journal of Marketing Theory and Practice”, Journal of Marketing Theory and Practice, Vol. 20 No. 3, 243-261.

Pritchard, A. (1969). "Statistical Bibliography or Bibliometrics”, Journal of Documentation, Vol. 25 No. 4, 348349.

Samiee, S. and Chabowski, B. R. (2012). "Knowledge Structure in International Marketing: A Multi-Method Bibliometric Analysis", Journal of the Academy of Marketing Science, Volume 40 Issue 2, 364-386.

Schlegelmilch, B. B. (2003). "Editorial: The Anatomy of an International Marketing Journal", Journal of International Marketing, Vol. 11 No. 1, 2-7.

Schwert, G. W. (1993). “The Journal of Financial Economics: A Retrospective Evaluation, 1974-91”, Journal of Financial Economics, Vol. 33 No. 3, 369-424.

Scimago Journal \& Country Rank, 2017 Marketing Journal Rankings. Retrieved from https://www.scimagojr.com/journalrank.php?area=1400\&category=1406 (06 March 2019). 
Scimago Journal \& Country Rank, 2016 Marketing Journal Rankings. Retrieved from https://www.scimagojr.com/journalrank.php?category=1406\&area=1400\&year=2016 (06 March 2019).

Scimago Journal \& Country Rank, 2015 Marketing Journal Rankings. Retrieved from https://www.scimagojr.com/journalrank.php?category=1406\&area=1400\&year=2015 (06 March 2019).

Scimago Journal \& Country Rank, 2014 Marketing Journal Rankings. Retrieved from https://www.scimagojr.com/journalrank.php?category=1406\&area=1400\&year=2014 (06 March 2019).

Scimago Journal \& Country Rank, 2013 Marketing Journal Rankings. Retrieved from https://www.scimagojr.com/journalrank.php?category=1406\&area=1400\&year=2013 (06 March 2019).

Scimago Journal \& Country Rank, 2012 Marketing Journal Rankings. Retrieved from https://www.scimagojr.com/journalrank.php?category=1406\&area=1400\&year=2012 (06 March 2019).

Scimago Journal \& Country Rank, 2011 Marketing Journal Rankings. Retrieved from https:/www.scimagojr.com/journalrank.php?category=1406\&area=1400\&year=2011 (06 March 2019).

Scimago Journal \& Country Rank, 2010 Marketing Journal Rankings. Retrieved from https://www.scimagojr.com/journalrank.php?category=1406\&area=1400\&year=2010 (06 March 2019).

Scimago Journal \& Country Rank, 2009 Marketing Journal Rankings. Retrieved from https://www.scimagojr.com/journalrank.php?category=1406\&area=1400\&year=2009 (06 March 2019).

Scimago Journal \& Country Rank, 2008 Marketing Journal Rankings. Retrieved from https://www.scimagojr.com/journalrank.php?category=1406\&area=1400\&year=2008 (06 March 2019).

Shugan, S. M. (2006). “Editorial: Fifty Years of Marketing Science”, Marketing Science, Vol 25, No. 6, 551-555.

Van Fleet, D., Ray, D. F., Bedeian, A. G., Downey, H. K., Hunt, J. G., Griffin, R. W., Dalton, D., Vecchio, R. P., Kacmar, K. M. and Feldman, D. C. (2006). "The Journal of Management's First 30 Years", Journal of Management, Vol. 32 No. 4, 477-506.

Van Raan, A. F. J. (2005). "For Your Citations Only? Hot Topics in Bibliometric Analysis", Measurement: Interdisciplinary Research and Perspectives, Volume 3 Issue 1, 50-62.

Vogel, R. and Güttel, W. H. (2013). "The Dynamic Capability View in Strategic Management: A Bibliometric Review", International Journal of Management Reviews, Vol. 15 Issue 4, 426-446.

Zhong, S., Geng, Y., Liu, W., Gao, C. and Chen, W. (2016). “A Bibliometric Review on Natural Resource Accounting During 1995-2014”, Journal of Cleaner Production, Volume 139, 122-132.

Zinkhan, G. M. and Leigh, T. W. (1999). “Assessing The Quality Ranking of The Journal of Advertising”, Journal of Advertising, Volume 28 Issue 2, 51-70. 